\title{
THE CONTRIBUTION OF THE EUROPEAN COURT OF JUSTICE TO THE COMMON AIR TRANSPORT POLICY: THE DECISIONS OF THE EUROPEAN COURT OF JUSTICE ON THE APPLICABILITY OF THE RULES OF THE TREATY OF ROME TO AIR TRANSPORT
}

\section{Professor Dr. Carl Otto LENZ*}

\section{CONTENTS}

Introduction: the issue

Applicability of the general Treaty provisions to air transport

The original attitude of the Commission

The applicability - initially restricted - of Article 85 of the EEC Treaty to air transport

Development of the legislation and of the case-law

The scope of application of secondary Community law in the area of air transport

The application of the prohibition of restrictive agreements under Article 85 of the EEC Treaty in relations with non-member countries

The unrestricted applicability of Article 86 of the EEC Treaty to air transport Problems in the application of the new law on air transport

Conclusion

Annex: Article 74 and Articles 84 to 90 of the EEC Treaty

- Advocat General at the Court of Justice of the European Community in Luxemburg 
Introduction: the issue

After the conclusion of the EEC Treaty the question whether and to what extent European Community law should be applicable in the area of air transport was initially one of some controversy. Article 3(e) of the EEC Treaty did include among the activities of the Community the adoption of a common policy in the sphere of transport. However, according to Article 84 (2), the concluding provision in Title IV of the Treaty, "Transport", it is for the Council to determine whether, to what extent and by what procedure appropriate provisions may be laid down for sea and air transport. As long as the Council had not adopted any such provisions, there could be some doubt as to the applicability of the EEC Treaty to aviation.

Moreover, it could be considered that having regard to the special relationships between Member States and airline companies recourse might be had to Article 90 of the EEC Treaty, which permits exceptions from the competition rules of the EEC Treaty in respect of certain undertakings which are entrusted with the operation of services of general economic interest.

The Community legislature itself contributed to a degree of legal uncertainty. On 6 February 1962 it did adopt a regulation implementing the competition provisions of the Treaty ${ }^{1}$, in order to ensure observance of the prohibition of anti-competitive agreements, decisions and concerted practices laid down in those provisions and to define the recpective functions of the Commission and the Court of Justice in that area. But in a further regulation of 26 November $1962^{2}$ the Council retroactively withdrew transport from the scope of application of the first implementing regulation, on the ground inter alia that with regard to sea and air transport it was impossible to foresee whether and at what date the Council would adopt appropriate provisions for the regulation of competition in those areas.

In view of that not entirely clear legal position it is understandable that for the step-by-step application of the rules of the EEC Treaty to the air transport sector clarification by means of decisions of the Court of Justice of

1 Regulation No. 17: First regulation implementing Articles 85 and 86 of the Treaty; Official Journal, English Special Edition 1959-1962, p. 87 (Official Journal 1962, p. 204)

2 Regulation No. 141 of the Council exempting transport from the appliction of Council Regulation No. 17; Official Journal, English Special Edition 1959-1962, p. 291 (Official Joumal 1962, p. 2751) 
the European Communities was necessary.

\section{Applicability of the general Treaty provisions to air transport}

A first step towards the clarification of these issues may be found in the judgment of the Court of Justice of 4 April 1974 in Case 167/73 $3^{3}$, which it should be noted dealt not with air transport but with sea transport. The Commission of the European Communities brought proceedings against the French Republic for failure to fulfil its obligations under the Treaty inasmuch as French legislation required a certain proportion of the crew of a ship to be of French nationality.

The Court of Justice was faced with the question whether, in the field of transport, the Member States were bound by the obligations laid down in Articles 48 to 51 of the Treaty, that is to say, whether they were required to ensure freedom of movement for workers in that field. The Court pointed out that Article 74, the basic porvision on transport policy, refers to the objectives of the Treaty and thus to the tasks and puropses of the Community as set out in Articles 2 and 3 of the EEC Treaty, for the attainment of which the fundamental provisions applicable to the whole complex of economic activity are of prime importance. Far from involving a departure from these fundamental rules, the object of the rules relating to the common transport policy is to implement and complement them by means of common action. Consequently, those general rules must be applied in so far as they help to achieve the objectives of the Treaty.

Since transport is basically a service, said the Court, it has been found necessary to provide a special system for it, taking into account the special aspects of this sector of the economy. Accordingly, a special exemption is provided by Article 61 (1), under which freedom to provide services in the field of transport is to be governed by the provisions of the title relating to transport, thus confirming that the general rules of the Treaty must be applied in so far as they are not excluded.

Article 84 (1) provides that the provisions of the title relating to transport shall apply to transport by rail, road and inland waterway. Article 84(2) provides that as regards sea transport, the Council may decide whether, to what extent and by what procedure appropriate provisions may be laid down.

3 Judgment of 4 April 1974 in Case 167/73, Commission v France, /1974/BCR 359 
Far from excluding the application of the Treaty to these matters, it provides only that the special provisions of the title relating to transport shall not automatically apply to them. From those points the Court of Justice drew the following conclusion, which, in view of its importance, I shall quote verbatim:

\begin{abstract}
"Whilst under Article 84 (2), therefore, sea and air transport, so long as the Council has not decided otherwise, is excluded from the rules of Title IV of Part Two of the Treaty relating to the common transport policy, it remains, on the same basis as the other modes of transpot, subject to the general rules of the Treaty. It thus follows that the application of Articles 48 to 51 to the sphere of sea transport is not optional but obligatory for Member States."
\end{abstract}

The Court thus made it clear that the general provisions of the Treaty must also apply in the field of transport. Those general Treaty provisions, it held, include the provisions on freedom of movement for workers - that conclusion was all that was necessary for the decision of the case. The Court was able to leave open the issue of which other provisions of the Treaty should be included among those general provisions. That issue too has subsequently given rise to differences of opinion, which were resolved only by the judgment of 30 April 1986 in joined Cases 209 to 213/844: I shall discuss that judgment in a moment.

\title{
The original attitude of the Commission
}

First, however, I must discuss the proceedings brought in 1981 by Lord Bethell, a Member of the European Parliament and of the House of Lords, against the Commission of the European Communities. I refer to that case, in which there was no decision on the merits, because it shows clearly the attitude of the Commission at the time to problems of air transport.

In reply to his complaint regarding alleged cartel agreements among airline companies the Commission explained to Lord Bethell its point of view regarding the fixing of air fares. An examination of air fares carried out with the co-operation of governmental experts had shown that in most cases the final fixing of air fares was the sole responsibility of the Member States, so

4 Judgment of 30 April 1986 in Joined Cases 209 to 213/84, Ministère Public v Asjes, /1986/ ECR 1425, sometimes referred to as the "Nouvelle Frontières" judgment. 
that there was in principle no ground to scrutinize the activity of airline companies on the basis of Article 85 of the EEC Treaty. However, bearing in mind the special relationships existing between the States and the airlines, the Commission would examine the subject further from the point of view of Articles $5^{5}$ and $90^{6}$ of the Treaty in conjunction with Article 86, regard being had to the fact that most scheduled airlines were in a dominant position within the common market. After emphasizing the difficulty and complexity of an analysis intended to establish the abusive nature of air fares, the Comission set out the further steps which it proposed to take: Transmission to the Council of a report on the examination it had effected; communication to the Member States drawing their attention to the fact that tariffs must not be unfair and thereby infringe Article 86; communication to the companies under Article 89 of the Treaty requesting full details of various arrangements and common rules relating to air transport; submission to the Council of a draft directive and a draft regulation applying Articles 85 and 86 of the Treaty to air transport, to supplement Regulation No. 17 .

Since Lord Bethell was not satisfied with that reply, he brought proceedings on the basis of Article 175 or in the alternative Article 173 of the EEC Treaty. The proceedings were dismissed. Although Lord Bethell, in his dual capacity as a user of the airlines and a leading member of an organization of airline passengers, had an interest in proceedings by the Commission against airline companies and their possible outcome, he did not have the necessary locus standi under Article 175 or the second paragraph of Article 173 of the EEC Treaty.

The applicability- initially restricted - of Article 85 of the EEC Treaty to air transport

The first actual decision on the applicability of the competition provisions of the EEC Treaty to the fixing of air fares came in the judgment of 30 April 1986 in Joined Cases 209 to 213/84, to which I have already referred.

In a reference for a preliminary ruling by the Tribunal de Police, Paris,

5 General obligation of the Member States to comply with the spirit of the Treaty

6 Special rules with regand to services of general economic interest

7 Judgment of 10 June 1982 in Case 246/81, Lord Bethell v Commlssion, /1982/BCR 2277 at page 2289 
the Court was called upon to determine whether a number of provisions of the French Civil Aviation Code were compatible with Community Law.

That question arose in criminal proceedings against executives of airlines and travel agencies who had been charged with infringing French legal provisions in the sale of air tickets by applying tariffs that had not been submitted to the Minister for Civil Aviation for approval or were different from that is cheaper than, the approved tariffs. A decision approving the tariff proposed by an airline had the effect of rendering that tariff binding on all trades selling tickets of that company in respect of the joumey specified in the application for approval.

The Tribunal de Police questioned the compatibility of that system with the EEC Treaty, in particular Article 85 (1), in asmuch as it made provision for concerted action between the airlines contrary to Article 85 .

The Advocate General delivered his opinion on 24 September 1985; the Court ruled on 30 April 1986.

Since the Court of Justice cannot, in preliminary reference proceedings under Article 177 of the EEC Treaty, rule on the compatibility of national law with Community law, it rephrased the question as follows: Is it contrary to the Member States' obligations to ensure that competition in the Common Market is not distorted ${ }^{8}$ to apply the provisions of a Member State which lay down a compulsory procedure for the approval of air tariffs and which make non-compliance with those approved tariffs punishable, inter alia by criminal penalties, where it is found that those tariffs are the result of an agreement, a decision or a concerted practice contrary to the competition provisions of the EEC Treaty?

As a preliminary point, the Court examined the issue whether the competition rules of the EEC Treaty are, as Community law now stands, applicable to airline companies.

The Court began by pointing out once more that under Article 74, that the first article in the title on transport, the objectives of the Treaty are, in matters governed by that title, to be pursued by Member States within the framework of the common transport policy. It is clear, it said, from the very wording of Article 74 that the objectives of th Treaty, including that set out

8 Cf. Articles 3 (f), 5 and 85 of the EEC Treaty 
in Article $3(f)$, namely the institution of a system ensuring that competition in the Common Market is not distorted, are equally applicable to the transport sector. Article 61 of the Treaty does provide that freedom to provide services in the field of transport is governed not by the provisions of the chapter on services but by those of the title relating to the common transport policy. However, no other provision in the Treaty makes its application to the transport sector subject to the realization of a common transport policy. Where the Treaty is intended to remove certain activities from the ambit of the competition rules, it makes an express derogation to that effect, as for example in the case of the Common Agricultural Policy. As regards transport there is no provision in the Treaty which excludes the application of the competition rules or makes it subject to a decision by the Council. As regards air transport in particular, it is clear from the wording of Article 84 and its position in the EEC Treaty that that article is intended merely to define the scope of the provisions of the common transport policy ${ }^{9}$ as regards different modes of transport, by distinguishing between transport by rail, road and inland waterway on the one hand and sea and air transport on the other. Article 84 (2) serves merely to exclude, so long as the Council has not decided otherwise, sea and air transport from the rules of Title IV of Part Two of the Treaty relating to the common transport policy.

It follows that air transport remains, on the same basis as the other modes of transport, subject to the general rules of the Treaty, including the competition rules.

After setting out these statements of principle, the Court turned its attention to the fact that in spite of an obligation in that respect the Council of Ministers had not yet adopted any implementing provisions regarding the application of competition rules to air transport. The Court concluded that the transitional provisions, not the general provisions on competition law, were applicable. According to the transitional provisions, until the entry into force of the required implementing provisions the authorities in the MemberStates ${ }^{10}$ are to rule on the admissibility of agreements, decisions and concerted practices and on abuse of a dominant position in the common market in accordance with the law of their country and with the competition provisions of the EEC Treaty. The Commission may ${ }^{11}$, on application by a Member

9 Articles 74 to 84 of the EEC Treaty

10 Article 88 of the EEC Treaty

11 Article 89 of the EEC Treaty 
State or on its own initiative, investigate cases in which infringement of the competition principles is suspected and, if it finds that there has been an infringement, take appropriate measures to bring that infringement to an end. If the infringement is not brought to an end, the Commission may record the infringement in a reasoned decision and authorize Member States to take the measures, the conditions and details of which it shall determine, needed to remedy the situation ${ }^{12}$.

However, at that time the Commission had not yet made any use of those powers.

In view of those circumstances the Court went on to raise the question whether, in the absence of implementing regulations or directives applicable to air transport adopted by the Council, a national court nevertheless had jurisdiction to rule that concerted tariff practices between airlines were contrary to the prohibition of agreements, decisions and concerted practices even though no decision had been taken by the competent national authorities ${ }^{13}$ or by the Commission ${ }^{14}$ regarding those practices.

Referring to its judgment of 6 April 1962 in Case $13 / 62^{15}$ - that is a judgement rendered during the first four year stage of the transitional period, the Court held that the transitional provisions of Articles 88 and 89 of the EEC Treaty are not of such a nature as to ensure a complete and consistent application of the prohibition of agreements, decisions and concerted practices laid down in Article 85 so that mere existence would permit the assumption that Article 85 had been fully effective from the date of entry into force of the Treaty. The fact that an agreement, decision or concerted practice might fall within the ambit of the prohibition does not, therefore, suffice for it to be regarded as prohibited by the EEC Treaty and thus automatically void $^{16}$. Such a conclusion would be contrary to the general principle of legal certainty, since it would have the effect of prohibiting and rendering automatically void certain agreements even before it is possible to ascertain whether Article 85 as a whole, and in particular the possibility of exemption under Article 85 (3), is applicable to those agreements.

12 Article 89 (2) of the EEC Treaty

13 Pursuant to Article 88 of the EEC Treaty

14 Pursuant to Article 89, in particular paragraph (2)

15 Judgment of 6 April 1962 in Case 13/61, Bosch v Van RIJn, /1962/ECR 45

16 Pursuant to Article 85 (2) of the EEC Treaty 
Finally, the Court turned to the question whether a national approval procedure for air tariffs was compatible with Community law. The Court had consistently held that while it was true that the competition provisions of the Treaty concern the conduct of undertakings and not laws or regulations of the Member States, nevertheless the Treaty imposes a duty on Member States not to adopt or maintain in force a measure which would deprive those provisions of their effectiveness. Such would be the case, in particular, if a Member State were to require or favour the adoption of agreements, decisions or concerted practices contrary to the Treaty or to reinforce their effect.

Where a decision has been taken by the competent national authorities or by the Commission ruling that the concerted action leading to the establishment of the air tariffs is incompatible with the prohibition laid down in the Treaty, it is contrary to the obligations of the Member States in the field of competition to approve such tariffs and thus to reinforce their effects.

The Court therefore replied to the question put by the Tribunal de Police, Paris, that it is contrary, under certain conditions, to the obligations of the Member States to approve air tariffs and thus to reinforce their effects where those tariffs are the result of an agreement, a decision by an association of undertakings, or a concerted practice ${ }^{17}$.

17 Wording of the decision:

"It is contrary to the obligations of the Member States under Article 5 of the EEC Treaty, in conjunction with Article 3 (f) and Article 85, in particular paragraph (1), of the EEC Treaty, to approve air tariffs and thus to reinfore the effects thereof, where, in the absence of any rules adopted by the Council in pursuance of Article 87, it has been found in accordance with the forms and procedures laid down in Article 88 or in Article 89 (2) that those tariffs are the result of an agreement, a decision by an association of undertakings, or a concerted practice contrary to Article 85."

In my Opinion delivered on 24 September 1985 I thought a more far-reaching answer to be appropriate,since I took the view that the principles laid down in the judgment of 6 April 1962 in Case 13/61 had been overtaken by later decisions of the Court. I therefore proposed that the Court should give the following ruling:

"National provisions which prescribe official approval for air tariffs and require or permit co-ordination of such tariffs between the airlines concemed prior to submission for approval are contrary to the Treaty establishing the European Economic Community, in particular the second paragraph of Article 5 in conjunction with Article 3 (f) and Article 85 - and, where appropriate, Article 90 - in so far as such prior co-ordination has not been exempted from the prohibition on cartels under Article 85 (3). 


\section{Development of the legislation and of the case-law}

Before delivery of the judgment in joined Case 209 to 213/84 delivered on 30 April 1986, but with knowledge of the Advocate General's Opinions delivered on 24 September 1985 the German Bundesgerichtshoft referred to the Court of Justice for a preliminary ruling a number of questions on the interpretaion of the competition provisions of the EEC Treaty in order to decide whether certain (national) practices in connection with the fixing of airline tariffs were compatible with those provisions. Those questions were raised in proceeding between the Zentrale zur Bekämpfung unlauteren Wettbewerbs, a German association campaigning against unfair competition, and two travel agents who obtained from airlines or travel agents established in another State airline tickets made out in the currency of that State. The travel agents were alleged to have infringed the prohibition in Germany on selling airline tickets at prices lower than those contained in the tariffs approved by the competent federal minister.

The Bundesgerichtshof referred three questions to the Court of Justice ${ }^{18}$ in which it broadened the issue, in comparison with Joined Cases 209 to $213 / 84$, by referring not only to the prohibition of agreements, decisions and concerted practices under Article 85 of the EEC Treaty but also to Article 86 (abuse of a dominant position) and the special provisions for publicly owned

It is for the national court to ensure that such provisions are not applied. It should apply them only if obligations arising under air transport agreements between Member States and non-member countries covered by Article 234 of the EEC Treaty require the Member State concemed to act in a manner contrary to Community law and if that Member State has not hitherto found it possible to bring its agreement with a nonmember country into conformity with Community law or denounce the agreement." $U$ $1986 /$ ECR 1427 at page 1454)

18 "1. Are bilateral or multilateral agreements regarding airline tariffs applicable to scheduled flights (for example, IATA resolutions) to which at least one airline with its registered office in a Member State of the EEC is a party void for infringement of Article 85 (1) of the EEC Treaty as provided for in Article 85 (2), even if neither the relevant authority of the Member State concerned (Article 88) nor the Commission (Article 89 (2)) has declared them incompatible with Article 85 ?

2. Does charging only such tariffs for scheduled flights constitute an abuse of a dominant position in the common market within the meaning of Article 86 of the EEC Treaty?

3. Is the approval of such tariffs by the competent authority of a Member State incompatible with the second paragraph of Article 5 and Article 90 (1) of the EEC Treaty and therefore void, even if the Commission has not objected to such tariff approval (Article 90 (3)?" Judgment of the Court of Justice of 11 April 1989 in Case 66/86, Ahmed Saeed Flugrelsen v Zentrale zur Bekämpfung unlauteren Wettbewerbs, not yet published. 
companies (Article 90 of the EEC Treaty). Moreover, during the course of the proceedings the Community legislature became active, and on 14 December 1987 adopted a number of measures which inter alia concemed the application of the competition rules to airlines ${ }^{19}$. On the basis of the measures adopted by the Council, the Commission adopted a number of regulations on the application of Article 85 (3) of the EEC Treaty to certain categories of agreements between undertakings, decisions of associations of undertakings and corcerted practices ${ }^{20}$.

\section{The scope of application of secondary Community law in the area of air transport}

After examining those measures the Court held that the Community provisions on air transport adopted by the Council apply only to international air transport services between Community airports. It followed that domestic air transport and air transport to and from airports in non-member countries continue to be subject to the transitional provisions ${ }^{21}$ and that in respect of such

19 Council Regulation (EEC) No. 3975/87 of 14 December 1987 laying down the procedure for the application of the rules on competition to undertakings in the air transport sector, Council Regulation (EEC) No. 3976/87 of 14 December 1987 on the application of Article 85 (3) of the Treaty to certain categories of agreements and concerted practices in the air transport sector;

Council Directive of 14 December 1987 on fares for scheduled air services between Member States $(87 / 601 / \mathrm{EEC})$;

Council Decision of 14 December 1987 on the sharing of passenger capacity between air carriers and scheduled air services between Member States and on access for air carriers to scheduled air service routes between States (87/602/EEC);

Official Joumal 1987 No. L 374, p. 1 et seq.

20 Commission Regulation (EEC) No. 2671/88 of 26 Jully 1988 on the application of Article 85 (3) of the Treaty to certain categonies of agreements between undertakings, decisions of associations of undertakings and concerted practices concerning joint planning and coordination of capacity, sharing of revenue and consultations on tariffs on scheduled air services and slot allocation at airports; Official Journal 1988 No. L 239, p.9;

Commission Regulation (EEC) No. 2672/88 of 26 July 1988 on the application of Article 85 (3) of the Treaty to certain categories of agreements between undertakings relating tocomputer reservation systems for air transport services; Official Journal1988 No. L 239, p. 13;

Commission Regulation (EEC) No. 2673/88 of 26 July 1988 on the application of Article 85 (3) of the Treaty to certain categories of agreements between undertakings, decisions of associations of undertakings and concerted practices concerning ground handling services; Official Journal 1988 No. L 289, p. 17

21 Articles 88 and 89 of the EEC Treaty 
services the system described in the judgment of 30 April 1986 in Joined Cases 209 to $213 / 84$ still applies.

With regard to tariff agreements falling within the new rules adopted by the Council, that is to say agreements relating to tariffs for scheduled flights between airports in different Member States, the Court observed that such agreements cannot qualify for exemption under Commission regulations ${ }^{22}$. Moreover, it is expressly provided ${ }^{23}$ that the block exemption for agreements on tariff consultations applies only where consultations do not entail agreement on agents' remuneration or other elements of the tariffs discussed.

Consequently, tariff agreements in respect of international intraCommunity flights are automatically void, subject to an objection procedure provided for in a Council regulation ${ }^{24}$. That is to say, an airline may consider that an agreement in respect of tariffs is part of a more comprehensive arrangement which may, in view of its beneficial economic effects, quality for individual exemption from the prohibition, and the airline may make an application to the Commission to that effect. Under the objection procedure the agreement is deemed to qualify for exemption once 90 days have elapsed following publication of the application in the Official Journal, if the Commission has not expressed doubts as to the applicability to the agreement of the criteria for exemption.

The application of the prohibition of restrictive agreements under Article 85 of the EEC Treaty in relations with non-member countries

In these proceedings the Court of Justice did not deal expressly with the issue whether the prohibition of agreements, decisions and concerted practices in Article 85 of the EEC Treaty is also applicable to airline tariff agreements where all the airlines concerned are based outside the Community. That issue has since been clarified, however. In a judgment of 27 September $1988^{25}$ the Court of Justice held that an infringement of the Article 85 prohibition consists of conduct made up of two elements: the formation of the agreement, decision or concerted practice and its implementation. If the ap-

22 Council Reglutaion No. 3976/87 does not provide for this

23 Article 4 (1) (f) of Commission Regulation No. 2673/88

24 Article 5 of Council Regulation No. 3975/87

25 Cf. judgment of 27 September in joined Cases 89, 104, 114, 116, 117, 125, 126, 127, 128 and 129/85, A. Ahlströhm Osakeytió and Others v Comlsslon, not yet published. 
plicability of prohibitions laid down under competition law were made to depend on the place where the agreement was formed, the result would obviously be to give companies an easy means of evading those prohibitions. The decisive factor is therefore the place where the agreement is implemented.

Where agreements between companies from non-member countries relate to international air transport between airports within the Community, the applicability of the prohibition on agreements, decisions and concerted practices thus depends on the place where the agreement is implemented. There should be no doubt that that place is in the Community.

With regard to tariff agreements between airlines based in non-member countries concerning flights between the Community and non-member countries there is not yet any secondary Community law. In the Court's view the transitional provisions of Articles 88 and 89 of the EEC Treaty and the rules laid down in the judgment of 30 April 1986 in joined Cases 209 to 213/84 therefore continue to apply. That means that in principle the Commission of the European Communities or the responsible Member State authorities may take action against such agreements. However, individuals may not challenge such agreements before the national courts on the basis that they are contrary to Article 85 of the Rome Treaty ${ }^{26}$.

\section{The unrestricted applicability of Article 86 of the EEC Treaty to air transport}

With regard to the applicability of Article 86 of the EEC Treaty (prohibition of abuse of a dominant position) the Court of Justice first addressed the issue whether it was necessary to draw a distinction, like that made in respect of Article 85, between international flights between airports in Member States and other flights. That point of view was put forward by the Commission and the United Kingdom, relying on the judgment in Joined Cases 209 to $213 / 84$.

The Court held first of all that the sole justification for the continued application of the transitional rules set out in Articles 88 and 89 of the EEC Treaty is that the agreements, decisions and concerted practies covered by Article 85 (1) may qualify for exemption under Article 85 (3) and that it is

26 In my opinion in Joined Cases 209 to 213/84 I argued for more extensive direct applicability of the probibition on restrictive agreements; cf. footnote 17, supra. 
through the decisions taken by the institutions which have been given jurisdiction, under the implementing rules adopted pursuant to Article 87, to grant or refuse such exemption that competition policy develops.

In contrast, no exemption may be granted, in any manner whatsoever, in respect of abuse of a dominant position. Such abuse is simply prohibited by the Treaty, and it is for the competent national authorities or the Commission, as the case may be, to act on that prohibition within the limits of their powers. The necessary conclusion is that the prohibition laid down in Article 86 of the Treaty is fully applicable to the whole of the air transport sector.

The Court of Justice then had to address the question whether the application of a tariff may as a matter of principle constitute an abuse of a dominant position where it is the result of concerted action between two undertakings which, itself, is capable of falling within the prohibition set out in Article 85 (1).

The typical example of an agreement, decision or concerted practice falling within Article 85 is where two undertakings which are economically independent of each other engage, by concerted action, in price fixing or other restrictions of competition on the relevant market. That does not exclude the possibility that an agreement between two or more undertakings may simply constitute the formal measures setting the seal on an economic reality characterized by the fact that an undertaking in a dominant position has succeeded in having the tariffs in question applied by other undertakings. In such a case Articles 85 and 86 of the EEC Treaty may very well both be applicable. Consequently, in certain cases Article 86 may cover the application of tariffs for scheduled flights on a particular route or routes where those tariffs were fixed by bilateral or multilateral agreements concluded between air carriers, provided that the conditions laid down in that article are satisfied.

Following those statements of principle the Court discussed examples relating to the particular case, on the basis of which the national court might apply that provision. I shall not go into detail here.

With regard to the legality of approval by the Member States of tariffs contrary to Article 85 (1) or Article 86 of the Treaty the Court began by pointing out once more that while it is true that the competition rules set out in Articles 85 and 86 of the EEC Treaty concern the conduct of undertakings and not measures of the authorities in the Member States, Article 5 of the Treaty nevertheless imposes a duty on those authorities not to adopt or main- 
tain in force any measure which could deprive those competition rules of their effectiveness. However, Article 90 (2) might entail consequences for decisions by the aviation authorities with regard to the approval of tariffs. That paragraph provides inter aila that undertakings entrusted with the operation of services of general economic interest are subject to the competition rules contained in the Treaty only in so for as the application of such rules does not obstruct the performance of the particular tasks assigned to them. It may thus be applied to carriers who may be obliged by the public authorities to operate on routes which are not commercially viable but which is necessary to operate for reasons of the general interest. It is necessary in each case for the competent national administrative or judicial authorities to establish whether the airline in question has actually been entrusted with the task of operating on such routes by an act of the public authority.

However, for it to be possible for the effect of the competition rules to be restricted pursuant to Article 90 (2) by needs arising from performance of a task of general interest, the national authorities responsible for the approval of tariffs and the courts to which disputes relating thereto are submitted must be able to determine the exact nature of the needs in question and their impact on the structure of the tariffs applied by the airlines in question.

\section{Problems in the application of the new law on air transport}

In closing I should like to mention a case ${ }^{27}$ which is currently pending before the Court and concerns the interpretation of Council Decision 87/602 of 14 December 1987 on the sharing of passenger capacity between air carriers on scheduled air services between Member States and on access for air carriers to scheduled air service routes between Member States.

The case concerns the refusal of the Italian authorities to grant the Irish airline Aer Lingus, which already has third and fourth freedom rights between Dublin and Manchester and Dublin and Milan, fifth freedom rights between Manchester and Milan.The Commission of the European Communities has brought Treaty infringement proceedings against Italy in respect of that refusal, since it takes the view that Article 8 (1) of the decision has been interpreted too restrictively by the Italian authorities.

27 Case 352/88, Commlssion v Italle, entered in the Registry on 9 December, 1988 


\section{Conclusion}

It would be interesting to complete this necessarily "court centered" account of the Court's contribution to the application of the competition rules of the Treaty of Rome to Air Transport by observations of the Member States and the Community institutions especially the Commission. 


\section{Time table}

1962

February The anti-cartel Regulation (No. 17) becomes effective

November Transport is withdrawn from the scope of application of Regulation No 17

$1974 \quad$ French and Communtiy law (1)

French mariners'Case (ECR 74/359)

Articles 48-51 applicable to sea transport

1981 The Commission's original attitude on the applicability of the competion rules of the Treaty to air transport French and Community law (2) The Novelles Frontières Case is laid before the Court (applicability of Article 85 to air transport)

The Advocate General delivers his opinion in the Nouvelles Frontières Case

1986 January German and Community law

The Saeed Case is laid before the Court (applicability of Articles 85, 86 and 90 to air transport)

April The Court decides to Nouvelles Frontières Case: no direct applicability of Article 85 to air transport (ECR 86/1427)

1988 January The Communities air transport Regulations become effective concerning Council Decision 87/602/EEC on access for air carriers to scheduled air service routes between Member States

December The Aer Lingus Case is laid before the Court (352/88) 1989 April The Saaed Case is decided The Court confirms the Nouvelles Frontières decision as to Article 85, declares Article 86 directly applicable and rules on the applicability of Article 90

September The Gibraltar case is heard before the Court (298/89) concerning Council Directive 89/463/EEC on scheduled interregional air services 


\section{Article 74}

The objectives of this Treaty shall in matters governed by this Title, be pursued by Member States within the framework of a common transport policy.

\section{Article 75}

1. For the purpose of implementing Article 74, and taking into account the distinctive features of transport, the Council shall, acting unanimously until the end of the second stage and by a qualified majority thereafter, lay down, on a proposal from the Commission and after consulting the Economic and Social Committee and the European Parliament:

(a) common rules applicable to international transport to or from the territory of a Member State or passing across the territory of one or more Member States;

(b) the conditions under which non-resident carriers may operate transport services within a Member State;

(c) any other appropriate provisions.

2. The provisions referred to in (a) and (b) of paragraph 1 shall be laid down during the transitional period.

3. By way of derogation from the procedure provided for in paragraph 1 , where the application of provisions concerning the principles of the regulatory system for transport would be liable to have a serious effect on the standard of living and on employment in certain areas and on the operation of transport facilities, they shall be laid down by the Council acting unanimously. In so doing, the Council shall take into account the need for adaptation to the economic development which will result from establishing the common market.

\section{Article 81}

Charges or dues in respect of the crossing of frontiers which are charged by a carrier in addition to the transport rates shall not exceed a reasonable level after taking the costs actually incurred thereby into account. 
Member States shall endeavour to reduce these costs progressively.

The Commission may make recommendations to Member States for the application of this Article.

\section{Article 82}

The provisions of this Title shall not from an obstacle to the application of measures taken in the Federal Republic of Germany to the extent that such measures are required in order to compensate for the economic disadvantages caused by the division of Germany to the economy of certain areas of the Federal Republic affected by that division.

\section{Article 83}

An Advisory Committee consisting of experts designated by the Governments of Member States, shall be attached to the Commission. The Commission, whenever it considers it desirable, shall consult the Committee on transport matters without prejudice to the powers of the transport section of the Economic and Social Committee.

\section{Article 84}

1. The provisions of this Title shall apply to transport by rail, road and inland waterway.

2. The Council may, acting by a qualified majority, decide whether, to what extent and by what procedure appropriate provisions may be laid down for sea and air transport".

The procedural provisions of Article 75 (1) and (3) shall apply.**

* First subparagraph of paragraph 2 as amended by Article 16(5) of the SEA.

** Second subparagraph of paragraph 2 as amended by Article 16 (6) of the SEA. 


\section{CHAPTER 1 \\ RULES ON COMPETTTION \\ Section 1 \\ Rules applying to undertakings}

Article 85

1. The following shall be prohibited as incompatible with the common market: all agreements between undertakings, decisions by associations of undertakings and concerted practices which may affect trade between Member States and which have as their object or effect the prevention, restriction or distortion of competition within the common market, and in particular those which:

(a) directly or indirectly fix purchase or selling prices or any other trading conditions;

(b) limit or control production, markets, technical development, or investment;

(c) share markets or sources of supply;

(d) apply dissimilar conditions to equivalent transactions with other trading parties, thereby placing them at a competitive disadvantage;

(e) make the conclusion of contracts subject to acceptance by the other parties of supplementary obligations which, by their nature or according to commercial usage, have no connection with the subject of such contracts.

2. Any agreements or decisions prohibited pursuant to this Article shall be automatically void. 
3. The provisions of paragraph 1 may, however, be declared inapplicable in the case of;

- any agreement or category of agreements between undertakings;

- any decision or category of decisions by associations of undertakings;

- any concerted practice or cetegory of concerted practices;

which contributes to improving the production or distribution of goods or to promoting technical or economic progress, while allowing consumers a fair share of the resulting benefit, and which does not:

(a) impose on the undertakings concerned restrictions which are not indispensable to the attainment of these objectives;

(b) afford such undertakings the possibility of eliminating competition in respect of a substantial part of the products in question.

\section{Article 86}

Any abuse by one or more undertakings of a dominant position within the common market or in a substantial part of it shall be prohibited as incompatible with the common market in so far as it may affect trade between Member States.

Such abuse may, in particular, consist in:

(a) directly or indirectly imposing unfair purchase or selling prices or other unfair trading conditions;

(b) limiting production, markets or technical development to the prejudice of consumers;

(c) applying dissimilar conditions to equivalent transactions with other trading parties, thereby placing them at a competitive disadvantage;

(d) making the conclusion of contracts subject to acceptance by the other parties of supplementary obligations which, by their nature or according to commercial usage, have no connection with the subject of such contracts. 


\section{Article 87}

1. Within three years of the entry into force of this Treaty the Council shall, acting unanimously on a proposal from the Commission and after consulting the European Parliament, adopt any appropriate regulations or directives to give effect to the principles set out in Articles 85 and 86 .

If such provisions have not been adopted within the period mentioned, they shall be laid down by the Council, acting by a qualified majority on a proposal from the Commission and after consulting the European Parliament.

2. The regulations or directives referred to in pargraph 1 shall be designed in particular:

(a) to ensure compliance with the prohibitions laid down in Article 85 (1) and in Article 86 by making provision for fines and periodic penalty payments;

(b) to lay down detailed rules for the application of Article 85 (3), taking into account the need to ensure effective supervision on the one hand, and to simplify administration to the greatest possible extent on the other;

(c) to define, if need be, in the various branches of the economy, the scope of the provisions of Articles 85 and 86;

(d) to define the respective functions of the Commission and of the Court of Justice in applying the provisions laid down in this paragraph;

(e) to determine the relationship between national laws and the provisions contained in this Section or adopted pursuant to this Article.

\section{Article 88}

Until the entry into force of the provisions adopted in pursuance of Article 87, the authorities in Member States shall rule on the admissibility of agreements, decisions and concerted practices and on abuse of a dominant position in the common market in accordance with the law of their country and with the provisions of Article 85, in particular paragraph 3, and of Article 86. 


\section{Article 89}

1. Without prejudice to Article 88, the Commission shall, as soon as it takes up its duties, ensure the application of the principles laid down in Articles 85 and 86. On application by a Member State or on its own initiative, and in cooperation with the competent authorities in the Member States, who shall give it their assistance, the Commission shall investigate cases of suspected infringement of these principles. If it finds that there has been an infringement, it shall propose appropriate measures to bring it to an end.

2. If the infringement is not brought to an end, the Commission shall record such infringement of the principles in a reasoned decision. The Commission may publish its decision and authorize Member States to take the measures, the conditions and details of which it shall determine, needed to remedy the situation.

\section{Article 90}

1. In the case of public undertakings and undertakings to which Member States grant special or exclusive rights, Member States shall neither enact nor maintain in force any measure contrary to the rules contained in this Treaty, in particular to those rules provided for in Article 7 and Articles 85 to 94 .

2. Undertakings entrusted with the operation of services of general economic interest or having the character of a revenue-producing monopoly shall be subject to the rules contained in this Treaty, in particular to the rules on competition, in so far as the application of such rules does not obstruct the performance, in law or in fact, of the particular tasks assigned to them. The development of trade must not be affected to such an extent as would be contrary to the interests of the Community.

3. The Commission shall ensure the application of the provisions of this Article and shall, where necessary, address appropriate directives or decisions to Member States. 


\title{
Section 2
}

\author{
Dumping
}

\section{Article 91}

1. If during the transitional period, the Commission, on application by a Member State or by any other interested party, finds that dumping is being practised within the common market, it shall address recommendations to the person or persons with whom such practices originate for the purpose of putting an end to them.

Should the practices continue, the Commission shall authorize the injured Member State to take protective measures, the conditions and details of which the Commission shall determine.

2. As soon as this Treaty enters into force, products which originate in or are in free circulation in one Member State and which have been exported to another Member State shall, on reimportation, be admitted into the territory of the first-mentioned State free of all customs duties, quantitative restrictions or measures having equivalent effect. The Commission shall lay down appropriate rules for the application of this paragraph. 